ORIGINAL ARTICLE

\title{
SIXTEEN YEARS OF DERMATOMYCOSIS CAUSED BY Candida spp. IN THE METROPOLITAN AREA OF PORTO ALEGRE, SOUTHERN BRAZIL
}

\author{
Daiane HEIDRICH(1), Cheila Denise Ottonelli STOPIGLIA(1,2), Cibele Massotti MAGAGNIN(1), Tatiane Caroline DABOIT(1,3), Gerson VETTORATO(4), Taís Guarienti
} AMARO(4) \& Maria Lúcia SCROFERNEKER(1,5)

\begin{abstract}
SUMMARY
The yeasts of the genus Candida infect skin, nails, and mucous membranes of the gastrointestinal and the genitourinary tract. The aim of this study was to determine the prevalence of dermatomycoses caused by Candida spp., and their etiological aspects in the metropolitan area of Porto Alegre, Brazil. A retrospective study with data obtained from tertiary hospital patients, from 1996 to 2011 , was performed. The analyzed parameters were date, age, gender, ethnicity, anatomical region of lesions, and the direct examination results. For all the statistical analyses, $\alpha=0.05$ was considered. Among positive results in the direct mycological examination, $12.5 \%$ of the total of 4,815 cases were positive for Candida spp. The angular coefficient (B) was $-0.7 \%$ / year, showing a decrease over the years. The genus Candida was more prevalent in women (15.9\% of women versus $5.84 \%$ of men), and in addition, women were older than men ( 54 versus 47 years old, respectively). There was no difference between ethnic groups. The nails were more affected than the skin, with $80.37 \%$ of the infections in the nails (72.9\% in fingernails and $7.47 \%$ in toenails). Our study corroborates the literature regarding the preference for gender, age, and place of injury. Moreover, we found a decrease in infection over the studied period.
\end{abstract}

KEYWORDS: Epidemiology; Dermatology; Candida.

\section{INTRODUCTION}

Cutaneous candidiasis is a dermatomycosis caused by the genus Candida, especially C. albicans, which infects skin, nails, and mucous membranes of the gastrointestinal and the genitourinary tract ${ }^{1-4}$. This yeast is part of the normal skin microbiome in healthy individuals and only causes infection when the normal commensal balance is disturbed ${ }^{4}$.

Most infections caused by Candida spp. tend to appear in intertriginous areas with moist conditions created by maceration and occlusion $^{5}$. In these sites, the lesions are moist with prominent borders ${ }^{6}$. Treatment involves the use of topical antifungals such as ketoconazole cream or nystatin powder or cream, and in several cases oral treatment with ketoconazole or fluconazole are required ${ }^{4}$. Candida onychomycosis cause periungual lesions and inflammation (paronychia or perionix), onycholysis, or it may colonize other injuries s,7-9. $^{2}$ Oral treatment with itraconazole or fluconazole is commonly used ${ }^{4}$. It has been reported that Candida species are the main causes of onychomycosis ${ }^{10-13}$, representing more than $90 \%$ of onychomycosis caused by yeasts, and their prevalence worldwide is up to $29 \%{ }^{14}$. In a study conducted in Rio Grande do Sul
State, Brazil, from 1988 to 1997, the genus Candida accounted for $28.8 \%$ of onychomycosis ${ }^{15}$. Therefore, due to its high frequency in clinical practice, the aim of this study is to determine the prevalence of dermatomycoses caused by Candida spp. and their etiological aspects in the metropolitan area of Porto Alegre, Rio Grande do Sul, Brazil.

\section{MATERIAL AND METHODS}

\section{Patients}

A retrospective study was carried out using data from the direct mycological examination of all patients in attendance at the Department of Dermatology of the Complexo Hospitalar Santa Casa de Porto Alegre, in the south of Brazil, from January 1996 to December 2011. The research project was approved by the Hospital Ethics Committee under the protocol number 3484/11.

\section{Diagnostics}

Skin and nail samples were collected by means of scraping injured surfaces with microscope slides and sterile curettes. The material was

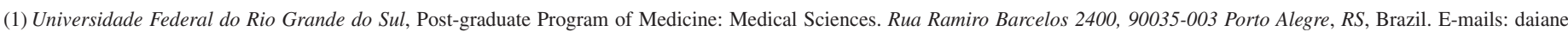
heidrich@yahoo.com.br; cheila.dos@gmail.com; cibele-mm@hotmail.com; scrofern@ufrgs.br

(2) Universidade Federal do Pampa. BR 472, KM 592, Cx.P. 118, 97500-970 Uruguaiana, RS, Brazil. E-mail: cheila.dos@ gmail.com

(3) Universidade Federal do Piauí. Av. São Sebastião 2819, 64202-020 Parnaíba, PI, Brazil. E-mail: tatidaboit@ gmail.com

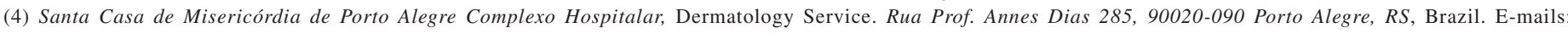
vetorato@terra.com.br; taisguarienti@terra.com.br

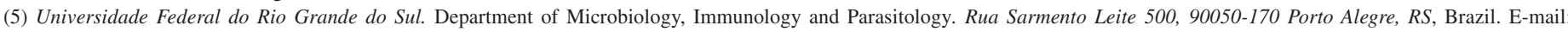
scrofern@ufrgs.br

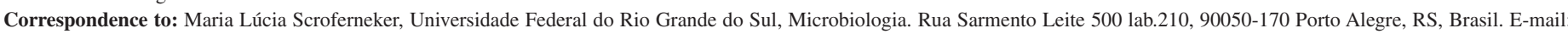
scrofern@ufrgs.br 
Heidrich D, Stopiglia CDO, Magagnin CM, Daboit TC, Vettorato G, Amaro TG, Scroferneker ML. Sixteen years of dermatomycosis caused by Candida spp. in the metropolitan area of Porto Alegre, Southern Brazil. Rev Inst Med Trop Sao Paulo. 2016;58:14.

clarified with potassium hydroxide at $20 \%$ and examined under optical microscope. The test for Candida spp. was considered positive when the characteristic blastoconidia and pseudohyphae of this genus were found $^{2,16}$. The presence of pseudohyphae in the material indicates infection, not colonization, by the genus Candida ${ }^{2}$.

\section{Collected data}

The analyzed parameters were date, age, gender, ethnicity, anatomical region of lesion, and the direct examination results. Then, according to the Brazilian Institute of Geography and Statistics (IBGE), white, brown (mixed ethnicity), and black ethnicity classifications were taken into consideration. The distribution of ethnic groups, called sample proportion, included all the subjects who underwent direct examination during the study period.

The anatomical areas with lesions were scalp, face, oral mucosa, trunk, arms, legs, groin and genital areas, feet, hands, toenails, and fingernails.

\section{Statistical analyses}

The statistical tests performed (considering $\alpha=0.05$ ), and the programs used for each specific analysis of the study were:

For the evaluation of the prevalence tendency of yeasts belonging to the genus Candida over the years, a simple linear regression was performed with the SPSS program, version 18, using the $\mathrm{x}$ and $\mathrm{y}$ coordinates as described: $\mathrm{x}=$ year; $\mathrm{y}=$ (number of yeasts belonging to the genus Candida in a year/total number of positive fungi tests in a year) x 100 .

For comparison of the prevalence of the genus Candida between the genders, the Pearson's Chi-square test was performed with the R Program, version 13.2 . In this analysis, $100 \%$ represented the total number of cases in each gender that were positive for mycological direct examinations, regardless of the fungus.

For comparison of the ages of patients infected by yeasts belonging to the genus Candida spp., between genders, the Mann-Whitney U test was performed with the SPSS program, version 18.

For comparison of the ethnic proportion of cases affected by Candida spp. with the sample proportion, the Chi-square test corrected by Bonferroni was performed with the WinPEPI program, version 11.25.

For each of the analysis, cases with missing values in the variables to be analyzed were excluded.

\section{RESULTS}

Of the 71,463 cases examined, 38,520 (53.9\%) were positive for fungi, and of these, $12.5 \%(4,815)$ were positive for Candida spp. The angular coefficient (B) was $-0.7 \%$ / year, showing a decrease over the years when compared with other direct examination results $(p<0.001)$. The genus Candida was more prevalent in women (15.9\% of women versus $5.84 \%$ of men), and in addition, affected women were older than men (54 versus 47 years, respectively) (Table 1). Figure 1 shows the percentages of male and female patients infected by Candida spp. In the different age groups, it is possible to deduce that younger men are more affected by these yeasts than women of the same age.

\section{Table 1}

Age and prevalence of dermatomycosis due Candida spp. between genders in the metropolitan area of Porto Alegre, Brazil (1996-2011)

\begin{tabular}{cccc}
\hline & \multicolumn{2}{c}{ Gender } & \multirow{2}{*}{$p$} \\
\cline { 2 - 3 } & Male & Female & \\
\hline Median Age (quartis 25/75) & $47(32 / 60)$ & $54(43 / 64)$ & $<0.01$ \\
number of cases & 722 & 3866 & \\
Infection (\%) & 5.84 & 15.9 & $<0.01$ \\
number of cases & 772 & 4039 & \\
$\begin{array}{l}\text { number of positive direct } \\
\text { examination for any fungi }\end{array}$ & 13223 & 25411 & \\
\hline
\end{tabular}

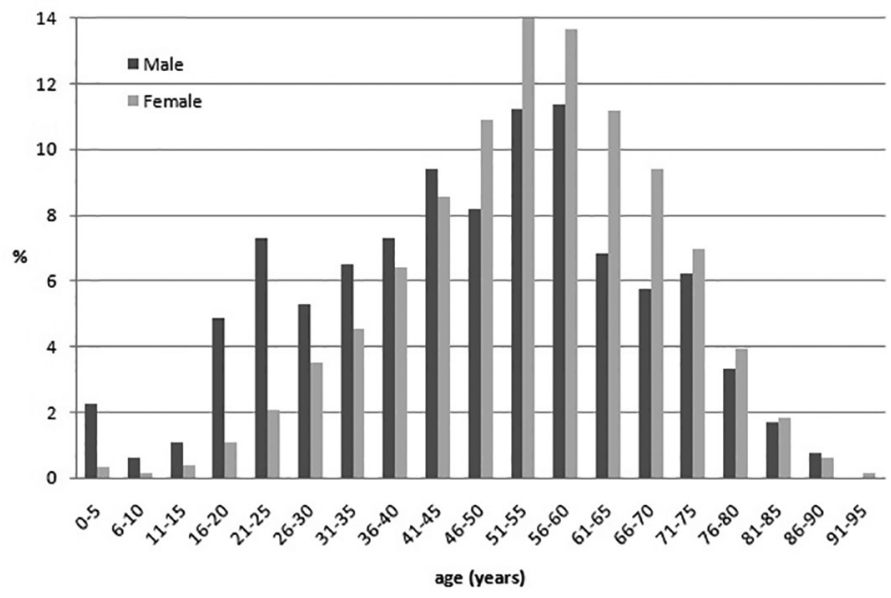

Fig. 1 - Age prevalence of male and female patients infected by Candida spp. in the metropolitan area of Porto Alegre, Brazil (1996-2011).

There was no significant difference between ethnic groups (Fig. 2).

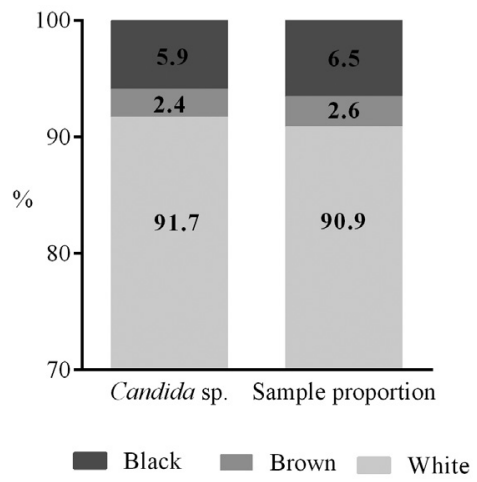

Fig. 2 - Ethnic proportion of infections caused by the Candida genus in comparison with the sample proportion (\%) in the metropolitan area of Porto Alegre, Brazil (1996-2011). $p=0.196$. Number of cases $=4,628$. Ethnic sample proportion $=$ all patients submitted to the mycological direct examination $(71,463)$. 
The nails were more affected $(80.4 \%)$ by the Candida genus than the skin, showing $72.9 \%$ of the infections in fingernails and $7.47 \%$ in toenails (Fig. 3).

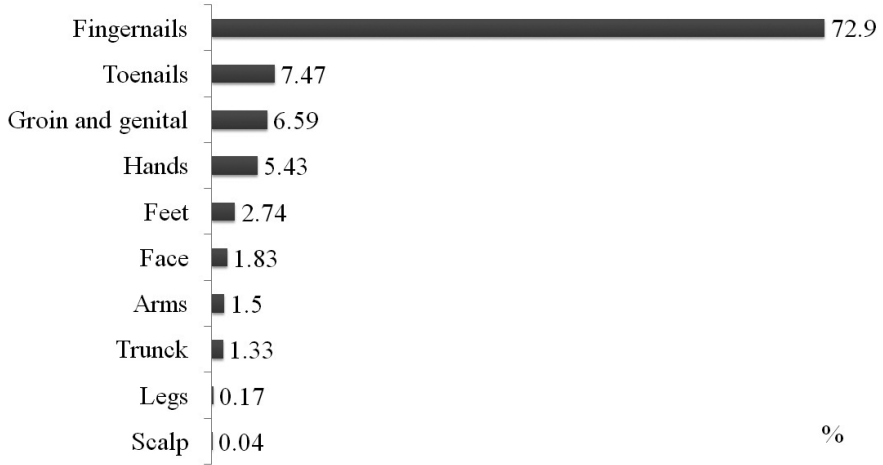

Fig. 3 - Prevalence of Candida spp. in anatomical sites of lesions (\%) in the metropolitan area of Porto Alegre, Brazil (1996-2011). Number of cases $=4,809$

\section{DISCUSSION}

Dermatomycoses are fungal infections that affect skin, hair, and nails and are caused by various etiologic agents. The fungi that most commonly cause cutaneous mycoses are dermatophytes and yeasts of the genera Candida and Malassezia ${ }^{17-19}$. Yeasts found in nails cited in the literature belong to the genera Candida, Trichosporon, Malassezia, Geotrichum, and Rhodotorula ${ }^{20-22}$. However, up to $90 \%$ of the superficial mycosis caused by yeasts have the genus Candida as the etiological agent ${ }^{14,23}$.

To our knowledge, this is the second study with the largest number of dermatomycoses cases caused by Candida spp., with 4,815 cases. The other study analyzed 6,227 cases from Croatia and observed an increase in infections caused by Candida spp. during the study period $(1999-2008)^{24}$. On the contrary, we found a decrease over the years in infections caused by this genus when compared with the other results of direct examination.

For this study, only results of the mycological direct examination were used because many patients lived far from the hospital and had low incomes, so that they would not be able to return for a second appointment in which the results of the fungal cultures would be available and the patients could receive the optimal treatment for mycosis. This is the reason why the doctors of the Hospital prescribe treatment according to the result of mycological direct examination.

Among the fungal structures found upon the direct examination, $12.5 \%$ were consistent with Candida yeasts. Discrepant results were obtained in other studies in which this genus was found in 16.2 to $71.9 \%$ of dermatomycoses, considering the fungal culture results ${ }^{24-26}$. In those studies, the results of the fungal culture were used in the surveys, whereas, in our study, data came from the results of the direct examination, a fact that may explain the differences found in our study. Furthermore, many tests were performed in the toenails during the study period (data not shown), probably overestimating the percentage of other fungi, such as dermatophytes, which have a closer relationship with the lesion site when compared with the genus Candida. The fingernails are the most commonly affected place by this yeast ${ }^{1,9,15,24,25,27-32}$, as also observed in this study.
Regarding the gender, $83.9 \%$ of those affected by Candida spp. were female, which is in accordance with many Brazilian studies and those from other countries that have reported higher prevalences of dermatomycoses caused by Candida species in women, especially onychomycosis $^{9,18,27-29,32-34}$. Some reasons for this fact are presented by the authors. Women are usually more concerned about their appearance and health than men ${ }^{18}$; the continued immersion of women's fingers in water, leading to macerated cuticles which can be a gateway for infections $s^{4,27,35}$; the maceration of periungual tissue caused by the use of manicure tools that were not properly disinfected can promote cross-infection among people who use this service ${ }^{18,36}$; and the contact with Candida organisms that reside in the intestine or vagina ${ }^{35,37}$. The last three reasons also explain why the yeast attacks fingernails more often than other parts of the body. Fingernail infection is considered to have an occupational nature, especially in professions that require a frequent contact with water ${ }^{18}$. The relationship between Candida spp. and water is so strong that VENUGOPAL et al. ${ }^{38}$ pointed out that the high prevalence of Candida genus found in toenails of patients was probably related to the Muslim religious practice of washing the feet five times a day.

When comparing men and women in relation to age, there was a statistical difference, namely, the women's age was higher than the men's. We also compared the proportion of ethnic groups affected, showing that there is no relationship between infection by Candida spp. and ethnicity. We did not find these analyses in other studies in the literature.

The median age was 53 years, corroborating the literature data ${ }^{18,27}$, and there is a low frequency of dermatomycoses among patients from both extremes of the age range (the youngest and the oldest patients). The low number of cases among children and adolescents is explained by several authors who affirm that onychomycosis, which constitutes the vast majority of cases and lesions caused by Candida spp., is rare before puberty, and some reasons for this fact are that at younger ages people have a faster rate of nail growth, making fungal infections at these sites more difficult ${ }^{39}$, and that onychomycosis caused by Candida spp. in children has been seen in fingernails only due to finger sucking habits ${ }^{40}$. Some investigators have claimed that children below the age of three are more vulnerable to onychomycosis caused by Candida species other than $C$. albicans such as $C$. glabrata $^{2,11,41}$. In elderly people, the low incidence of nail infection may be due to the fact that these patients search for a specific medical appointment only when the nail is too debilitated or due to other type of skin problems. Thus, the diagnosis of onychomycosis is usually a secondary diagnosis among elderly patients ${ }^{18}$. Health care providers should be aware that chronic and recurrent episodes of candidiasis in the elderly can be an indicator of an underlying condition such as diabetes, malignancy, vitamin deficiency, or malnutrition, and that appropriate investigation should be performed ${ }^{4}$.

In conclusion, our study corroborates the data in the literature regarding the higher number of females with dermatomycoses caused by the Candida genus; the fingernails are the most frequent site of infection; and the highest prevalence was observed in adulthood. Furthermore, we found that there is no relationship between this yeast and ethnicity, that women infected by Candida spp. are older than men, and that there was a decrease in dermatomycoses caused by Candida spp. over the sixteen years of study. Therefore, the continuation of long-term epidemiological studies in the metropolitan area of Porto Alegre, Brazil, is needed to 
Heidrich D, Stopiglia CDO, Magagnin CM, Daboit TC, Vettorato G, Amaro TG, Scroferneker ML. Sixteen years of dermatomycosis caused by Candida spp. in the metropolitan area of Porto Alegre, Southern Brazil. Rev Inst Med Trop Sao Paulo. 2016;58:14.

monitor the increase or decrease in the frequency of dermatomycoses related to Candida genus.

\section{ACKNOWLEDGMENTS}

The authors want to thank Prof. Cleusa Brilhante for her assistance in compiling the data, the Coordenação de Aperfeiçoamento de Pessoal de Nivel Superior (CAPES), and the Conselho Nacional de Desenvolvimento Científico e Tecnológico $(\mathrm{CNPq})$ for providing the scholarships.

\section{REFERENCE}

1.Cruz R, Ponce EE, Calderón LR, Delgado NV, Vieelle PO, Piontelli E. Micosis superficiales en la ciudad de Valparaíso, Chile. Período 2007-2009. Rev Chilena Infectol. 2011;28:404-9.

2. Jayatilake JA, Tilakaratne WM, Panagoda GJ. Candidal onychomycosis: a mini-review. Mycopathologia. 2009;168:165-73

3. Male O. The significance of mycology in medicine. In: Hawksworth DL, editor. Frontiers in mycology. Wallingford: CAB International; 1990.

4. Varade RS, Burkemper NM. Cutaneous fungal infections in the elderly. Clin Geriatr Med. 2013;29:461-78.

5. Lacaz CS, Porto E, Martins JEC, Heins-Vaccari EM, de Melo NT. Tratado de micologia médica Lacaz. $9^{\text {th }}$ ed. São Paulo: Sarvier; 2002.

6. Nenoff P, Krüger C, Schaller J, Ginter-Hanselmayer G, Schulte-Beerbühl R, Tietz HJ. Mycology - an update part 2: dermatomycoses: clinical picture and diagnostics. J Dtsch Dermatol Ges. 2014;12:749-77.

7. Elewski BE. Onychomycosis: pathogenesis, diagnosis, and management. Clin Microbiol Rev. 1998;11:415-29.

8. Kaur R, Kashyap B, Bhalla P. Onychomycosis-epidemiology, diagnosis and management. Indian J Med Microbiol. 2008;26:108-16.

9. Relloso S, Arechavala A, Guelfand L, Maldonado I, Walker L, Agorio I, et al. Onicomicosis: estudio multicéntrico clínico, epidemiológico y micológico. Rev Iberoam Micol. 2012;29:157-63.

10. Jesudanam TM, Rao GR, Lakshmi DJ, Kumari GR. Onychomycosis: a significant medical problem. Indian J Dermatol Venereol Leprol. 2002;68:326-9.

11. Lange M, Roszkiewicz J, Szczerkowska-Dobosz A, Jasiel-Walikowska E, Bykowska B. Onychomycosis is no longer a rare finding in children. Mycoses. 2006;49:55-9.

12. Veer P, Patwardhan NS, Damle AS. Study of onychomycosis: prevailing fungi and pattern of infection. Indian J Med Microbiol. 2007;25:53-6.

13. Vélez A, Linares MJ, Fenández-Roldán JC, Casal M. Study of onychomycosis in Córdoba, Spain: prevailing fungi and pattern of infection. Mycopathologia. 1997;137:1-8.

14. Mugge C, Haustein UF, Nenoff P. Causative agents of onichomycosis a retrospective study. J Dtsch Dermatol Ges. 2006;4:218-27.

15. Lopes JO, Alves SH, Mari CRD, Oliveira LTO, Brum LM, Westphalen JB, et al. A tenyear survey of onychomycosis in the central region o the Rio Grande do Sul, Brazil. Rev Inst Med Trop Sao Paulo. 1999;41:147-9.

16. López-Jodra O, Torres-Rodriguez JM. Especies fúngicas poco comunes responsables de onicomicosis. Rev Iberoam Micol. 1999;16:S11-5.

17. Campanha AM, Tasca RS, Svidzinski TIE. Dermatomicoses: freqüência, diagnóstico laboratorial e adesão de pacientes ao tratamento em um sistema público de saúde em Maringá-PR, Brasil. Lat Am J Pharm. 2007;26:442-8.
18. Costa-Orlandi CB, Magalhães GM, Oliveira MB, Taylor ELS, Marques CRS, de ResendeStoianoff MA. Prevalence of dermatomycosis in a Brazilian tertiary care hospital. Mycopathologia. 2012;174:489-97.

19. Crespo-Erchiga V, Delgado-Florencio V. Micosis cutáneas. Med Clin (Barc). 2005;125:467-74.

20. Meireles TE, Rocha MF, Brilhante RS, Cordeiro Rde A, Sidrim JJ. Successive mycological nail tests for onychomycosis: a strategy to improve diagnosis efficiency. Braz J Infect Dis. 2008;12:333-7.

21. Prohic A, Kuskunovic-Vlahovljak S, Sadikovic TJ, Cavaljuga S. The prevalence and species composition of Malassezia yeasts in patients with clinically suspected onychomycosis. Med Arch. 2015;69:81-4.

22. Pukhrambam PD, Devi KhR, Singh NB. Pattern of onychomycosis: a RIMS study. J Commun Dis. 2011;43:105-12.

23. Nasr A, Vyzantiadis TA, Patsatsi A, Louka A, Ioakimidou A, Zachrou E, et al Epidemiology of superficial mycoses in Northern Greece: a 4-year study. J Eur Acad Dermatol Venereol. 2015. doi: 10.1111/jdv.13121.

24. Miklić P, Skerlev M, Budimčić D, Lipozenčić J. The frequency of superficial mycoses according to agents isolated during a ten-year period (1999-2008) in Zagreb area, Croatia. Acta Dermatovenerol Croat. 2010;18:92-8.

25. Jankowska-Konsur A, Dylag M, Hryncewicz-Gwóz'dz' A, Plomer-Niezgoda E, Szepietowski JC. A 5-year survey of dermatomycoses in southwest Poland, years 2003-2007. Mycoses. 2009;54:162-7.

26. Wille MP, Arantes TD, da Silva JLM. Epidemiologia das dermatonicoses em população da periferia de Araraquara, SP. Rev Bras Clin Med. 2009;7:295-8.

27. Aghamirian MR, Ghiasian SA. Onychomycosis in Iran: epidemiology, causative agents and clinical features. Nihon Ishinkin Gakkai Zasshi. 2010;51:23-9.

28. de Araújo AJG, Bastos OMP, Souza MAJ, de Oliveira JC. Onicomicoses por fungos emergentes: análise clínica, diagnóstico laboratorial e revisão. An Bras Dermatol. 2003;78:445-55

29. Godoy-Martinez P, Nunes FG, Tomimori-Yamashita J, Urrutia M, Zaror L, Silva V, et al. Onychomycosis in São Paulo, Brazil. Mycopathologia. 2009;168:111-6.

30. Nazar JR, Gerosa PE, Díaz AO. Onicomicosis: epidemiología, agentes causales y evaluación de los métodos diagnósticos de laboratório. Rev Argent Microbiol 2012;44:21-5.

31. Segal R, Kimchi A, Kritzman A, Inbar R, Segal Z. The frequency of Candida parapsilosis in onychomycosis. An epidemiological survey in Israel. Mycoses. 2000;43:349-53.

32. Souza LKH, Fernandes OFL, Passos XS, Costa CR, Lemos JA, Silva MRR Epidemiological and mycological data of onychomycosis in Goiania, Brazil. Mycoses. 2010;53:68-71.

33. Manzano-Gayosso P, Méndez-Tovar LJ, Arenas R, Hernández-Hernández F, Millán-Chiu $\mathrm{B}$, Torres-Rodríguez JM, et al. Levaduras causantes de onicomicosis en cuatro centros dermatológicos mexicanos y su sensibilidad antifúngica a compuestos azólicos. Rev Iberoam Micol. 2011;28:32-5.

34. Scher P. Onychomycosis: a significant medical disorder. J Am Acad Dermatol. 1996;35(3 Pt2):S2-5.

35. Ahmed R, Kharal SA, Durrani MA, Sabir M, Chang AH, Fakharuddin. Frequency of Candida in onychomycosis. J Pak Med Assoc. 2013;63:350-3.

36. Lima KM, Rêgo RSM, Montenegro F. Espécies fúngicas isoladas a partir de unhas de manipuladores de alimentos. Rev Bras Anal Clin. 2007;39:193-6.

37. Zaias N, Glick B, Rebell G. Diagnosing and treating onychomycosis. J Fam Pract 1996;42:513-8. 

Alegre, Southern Brazil. Rev Inst Med Trop Sao Paulo. 2016;58:14.

38. Venugopal PV, Venugopal TV. Superficial mycoses in Saudi Arabia. Australas J Dermatol. 1992;33:45-8

39. Gupta M, Sharma NL, Kanga AK, Mahajan VK, Tegta GR. Onychomycosis: clinicomycologic study of 130 patients from Himachal Pradesh, India. Indian J Dermatol Venereol Leprol. 2009;73:389-92.
40. Nishimoto K. An epidemiological survey of dermatomycoses in Japan, 2002. Nikon Ishinkin Gakkai Zasshi. 2006;47:103-11

41. Gunduz T, Metin DY, Sacar T, Hilmioglu S, Baydur H, Inci R, et al. Onychomycosis in primary school children: association with socioeconomic conditions. Mycoses. 2006;49:431-3.

Received: 10 February 2015

Accepted: 27 August 2015 